\title{
A New Method for D-Glucaric Acid Excretion Measurement That Is Suitable for Automated Instruments
}

\author{
Paolo Mocarelli, ${ }^{1,2}$ Paolo Brambllia, ${ }^{2}$ Laura Colombo, ${ }^{2}$ Alessandro Marocchl, ${ }^{2}$ Carla Crespl, ${ }^{2}$ Plerluigl Tramacere, ${ }^{2}$ and Antonio \\ Mondonico ${ }^{2}$
}

Urinary excretion of D-glucaric acid (UGA) is an index of type II hepatic microsomal enzyme induction, indirectly revealing possible organic effects of some drugs and environmental pollutants. However, its determination is often cumbersome. We suggest a new, fast microanalytical method for UGA determination in which $\beta$-glucuronidase (BG; EC 3.2.1.31) activity inhibition produced by UGA-derived 1,4-D-glucarolactone is measured. With use of purified BG, the method is suitable for centrifugal analyzers, allowing assay of $>100$ samples per day. Moreover, the method measures UGA more accurately than other enzymatic methods based on BG inhibition. The within-day CV ranges from $7.9 \%$ to $4.6 \%$ (UGA 31.55-121.31 $\mu \mathrm{mol} / \mathrm{L})$; the between-day $\mathrm{CV}$ ranges from $11.5 \%$ to $5.0 \%$ (UGA 26.09-124.10 $\mu \mathrm{mol} / \mathrm{L}$ ). The detection limit is $6.0 \mu \mathrm{mol} / \mathrm{L}$. The standard curve is linear from 10 to $200 \mu \mathrm{mol} / \mathrm{L}$. Mean analytical recovery is $100 \%$. Comparison with the method of Simmons et al. (Clin Chim Acta $1974 ; 51: 47-51$ ) gave a correlation of $r=0.978, y=1.40 x-$ 2.81. Reference intervals were established in a healthy population sample of 369 people (165 under $14 \mathrm{y}$ ), and UGA, expressed in micromoles per gram of creatinine, was higher in women than in girls or in males.

Additional Koyphrases: effects of drugs, environmental pollutants - hepatic microsomal enzyme induction - centrifugal analyzer - reference interval - sex-and age-related effects - monitoring therapy - enzyme purification

Different xenobiotic substances, including environmental pollutants and drugs, can activate the drug-metabolizing system in liver microsomes and are metabolized mainly by the cytochrome P-450 system of mono-oxygenases and other enzymes of the smooth endoplasmic reticulum (1).

After exposure to an exogenous lipophilic substrate, the activities of substrate-specific mono-0xygenases increase, generating oxygen radicals that hydroxylate (so-called phase-I reaction) the exogenous substrate to metabolites, which undergo further enzymatic conjugation (e.g., to glucuronide) in the phase-II reaction and are then excreted.

Assessment of functional induction of the hepatic microsomal enzyme system is therefore valuable to predict the individual response to therapy, reveal individual or group exposure to chemicals, and correlate it with changes in metabolic activation and deactivation of hepatotoxic agents and carcinogens $(2,3)$.

The methods used to assess induction of the hepatic microsomal enzyme system are:

\footnotetext{
${ }^{1}$ Institute of General Pathology, Faculty of Medicine of University of Milan, Milano, Italy.

2 University Department of Clinical Pathology, Hospital of Desio, 20033 Desio (Milano), Italy.

Address correspondence to: P. Mocarelli, M.D., University Department of General Pathology and Clinical Pathology, Hospital of Desio, 20033 Desio (Milano), Italy.

Received July 13, 1988; accepted August 15, 1988.
}

1) in vitro determination of specific enzyme content and activity in liver biopsy specimens (4-6);

2) in vivo antipyrine or theophylline clearance, indicators of phase-I reactions $(7,8)$;

3) serum $\gamma$-glutamyltransferase (EC 2.3.2.2) determination (9-11);

4) urinary excretion of $6 \beta$-hydroxycortisol, indicator of phase-I reactions $(8,12,13)$; and

5) urinary excretion of D-glucaric (or D-saccharic) acid (uGA), indicator of phase-II reactions (14-18). ${ }^{3}$

Demonstrably $(2,3,14-18)$, uGA is a suitable indicator of liver microsomal enzyme induction, thus giving indirect information on the presence of foreign toxic substances (12, 19,20 ), although a recent paper (21) questions this assumption and suggests that uGA is a less-sensitive index than antipyrine clearance, at least for low doses of phenobarbital.

uGA can be quantified either by chromatography (22-24), which is complex and not particularly favored in a clinical laboratory, or by enzymatic methods (25-31).

These rely on two different principles:

1) uGA in urine is in equilibrium with 1,4- and 1,6glucarolactone (GL). Boiling urine at an acidic pH transforms uGA into 1,4-GL. uGA can be indirectly measured by means of the competitive inhibition that 1,4-GL exerts on the enzymatic activity of $\beta$-glucuronidases (EC 3.2.1.31) (BGs) on adequate substrates, such as phenolphthalein- $\beta$-Dglucuronide and 4-nitrophenyl- $\beta$-D-glucuronide (NP-G) (2530).

2) Treatment of uGA with a bacterial extract containing glucarate dehydratase (EC 4.2.1.40) and ketodeoxyglucarate aldolase (EC 4.1.2.20) leads to quantitative formation of pyruvate, which is then assayed by use of lactate dehydrogenase (EC 1.1.1.27) (31).

Table 1 lists advantages and disadvantages of both groups of methods.

For sample throughput to be high, tests based on enzymatic inhibition $(26-30)$ are usually preferred. Here we report a new method for uGA assay, which is faster, yielding about $100 \mathrm{uGA}$ determinations per day, but is as precise and accurate as previous procedures.

For reasons of economy we also propose a method to produce, through simple chromatographic purification of BG, an enzyme suitable for uGA determination that will be sufficiently sensitive to inhibition by 1,4-GL-although the method also works with a commercially available BG.

\section{Materials and Methods}

\section{Specimen Collection and Preparation}

Specimens of first morning urine from apparently healthy people were stored at room temperature if analyzed the

\footnotetext{
3 Nonstandard abbreviations: uGA, urinary D-glucaric acid; GA, D-glucaric acid; BG, $\beta$-glucuronidase; GL, D-glucarolactone; NP-G, 4-nitrophenyl- $\beta$-D-glucuronide; PBS, phosphate-buffered isotonic saline; CRE, creatinine; Con-A, concanavalin A.
} 
Table 1. Outtines of Analytical Methodologles for Urinary D-Glucaric Acld Determination

\begin{tabular}{|c|c|c|c|c|c|c|}
\hline Ret. no. & Method & $\begin{array}{l}\text { Specimen } \\
\text { preparation }\end{array}$ & BQ"purfilication & Analytical steps & Callbration curve & Interference \\
\hline 25 & Enzymatic inhibition & $\begin{array}{l}\text { 1)Acid-boiling } \\
\text { 2)Alkali-boiling (blank) }\end{array}$ & Complete BG purification & Multistep manual & Exponential & $\begin{array}{l}\text { Subtraction of } \\
\text { blank value }\end{array}$ \\
\hline 22 & Liquid chromatography & Not required & Not required & Multistep manual & Linear & $\begin{array}{l}\text { By ascorbic } \\
\text { acid }\end{array}$ \\
\hline 23 & Gas chromatography & $\begin{array}{l}\text { 1) Acid-boiling } \\
\text { 2) Silanization }\end{array}$ & Not required & One-step manual & Linear & Not described \\
\hline 26 & Enzymatic inhibition & $\begin{array}{l}\text { 1) Acid-boiling } \\
\text { 2) Alkali-boiling (blank) }\end{array}$ & Not required & Multistep manual & Exponential & $\begin{array}{l}\text { Subtraction of } \\
\text { blank value }\end{array}$ \\
\hline 27 & Enzymatic inhibition & $\begin{array}{l}\text { 1) Acid-boiling } \\
\text { 2) Alkali-boiling (blank) }\end{array}$ & Complete BG purification & Multistep manual & Linear & $\begin{array}{l}\text { Subtraction of } \\
\text { blank value }\end{array}$ \\
\hline 24 & HPLC & Not required & Not required & One-step manual & Linear & $\begin{array}{l}\text { By biol. } \\
\text { matrices }\end{array}$ \\
\hline 28 & Enzymatic inhibition & Acid-boiling & Not required & Multistep manual & Linear & $\begin{array}{l}\text { Not taken into } \\
\text { account }\end{array}$ \\
\hline 31 & $\begin{array}{l}\text { Enzymatic detn. by } \\
\text { conversion to } \\
\text { oynuvate }\end{array}$ & $\begin{array}{l}\text { Ion-exchange } \\
\text { chromatography }\end{array}$ & Bacterial BG preparation & Multistep manual & Linear & $\begin{array}{r}\text { Subtraction of } \\
\text { blank value }\end{array}$ \\
\hline 30 & Enzymatic inhibition & Acid-boiling & Not required & $\begin{array}{l}\text { Multistep } \\
\text { semiautomated }\end{array}$ & Linear & $\begin{array}{l}\text { Not reported } \\
\text { in abstract }\end{array}$ \\
\hline
\end{tabular}

same day or at $-20^{\circ} \mathrm{C}$ if analysis was delayed. Samples were centrifuged (10 min, $2000 \times g)$ immediately before analysis.

\section{Reagents}

The following reagents were used: BG/arylsulfatase (EC 3.2.1.31/EC 3.1.6.1) from Helix pomatia, stabilized solution (code 127 698, lot 10003320; Boehringer, Mannheim, F.R.G.); BG from Haliotis midae (code 36-203, lot 32; Miles Italiana, Cavenago Brianza, Milano, Italy); BG from bovine liver (code G-0501); BG from Patella vulgata (code G-8132, lot 92F-3913); BG from Helix pomatia, partially purified by gel permeation chromatography (code G-1512, lot 73F71851; Sigma Chemical Co., St. Louis, MO); NP-G (Boehringer); Sepharose CL-6B, Con-A Sepharose 4B (Pharmacia, Uppeala, Sweden); methyl-4-D-mannoside (grade III, Sigma); "Total Protein, Lowry Micro Method" kit (Sigma); "Creatinine Merckotest A" (Merck, Darmstadt, F.R.G.); and distilled water with a resistance of more than $10 \mathrm{M} \Omega$, prepared with a "MilliQ" unit (Millipore, Bedford, MA).

\section{Standards}

The D-saccharic acid (glucaric acid; GA), monopotassium salt, used as a standard was supplied by Sigma and was prepared daily from a stock $200 \mu \mathrm{mol} / \mathrm{L}$ solution in distilled water (stable for 12 months at $-80^{\circ} \mathrm{C}$ ).

\section{Apparatus}

The diluter used was a Model 2075 (LKB, Bromma, Sweden) and the pH-meter was a Model PW 9408 (Philips, Cambridge, U.K.). Throughout the study we used either a Cobas Bio or a Cobas Fara (Roche, Basel, Switzerland) centrifugal analyzer.

\section{BG Purification}

Dilute $1 \mathrm{~mL}$ of the BG original solution with $4 \mathrm{~mL}$ of phosphate-buffered saline (PBS), load on a Con-A Sepharose-CL-4B column (10 mL, bed height $5 \mathrm{~cm})$, wash with four bed volumes of PBS, elute with one bed volume of methyl-4-D-mannoside, $20 \mathrm{mmol} / \mathrm{L}$ in $\mathrm{PBS}$, collect fractions of the eluate, and test them for BG activity.

Analytical recovery of the enzyme activity is usually $80 \%$ (stable for at least six months if stored at $4^{\circ} \mathrm{C}$ ).

Alternatively, to save on the cost of Con-A-coupled resin, chromatograph at room temperature $\left(25^{\circ} \mathrm{C}\right), 5 \mathrm{~mL}$ of the $B G$ original solution on a CL-6B-Sepharose column $(72 \mathrm{~mL}$, bed height $36 \mathrm{~cm}$ ), with PBS (pH 7.4, phosphate $10 \mathrm{mmol} / \mathrm{L}$ ) containing $\mathrm{NaCl} 130 \mathrm{mmol} / \mathrm{L}, \mathrm{KCl} 2.7 \mathrm{mmol} / \mathrm{L}, \mathrm{CaCl}_{2} 0.9$ $\mathrm{mmol} / \mathrm{L}$, and $\mathrm{MgCl}_{2} 0.5 \mathrm{mmol} / \mathrm{L}$ as eluent. Collect and test fractions for BG activity in acetate buffer (pH 5.0, $0.8 \mathrm{~mol} / \mathrm{L}$ ) with NP-G, $1 \mathrm{mmol} / \mathrm{L}$ (final concentration), at $37^{\circ} \mathrm{C}$ and read the absorbance at $401 \mathrm{~nm}$.

Pool the fractions containing more than $5 \%$ of the total activity applied to the column. Chromatograph the pool at room temperature on a Con-A Sepharose-CL-4B column (10 $\mathrm{mL}$, bed height $5 \mathrm{~cm}$ ), wash with two bed volumes of PBS, then elute with one bed volume of methyl-4-D-mannoside, 20 mmol/L in PBS. Analytical recovery and stability of the purified enzyme are as above.

\section{Study of the Specific Activity of BG}

Add one volume of the diluted BG solution to one volume of NP-G, $5 \mathrm{mmol} / \mathrm{L}$, and measure the activity as the absorbance increase per minute at $401 \mathrm{~nm}$ in the linear range. Measure the total protein content of the eluate by the "Total Protein, Lowry Micro Method" (see Reagents). Divide the absorbance increase per minute by the protein concentration to find the specific activity of BG per gram of protein.

\section{$K_{m}$ Determination for NP-G}

For each BG preparation, dilute the enzyme solution in a tube with acetate buffer ( $1 \mathrm{~mol} / \mathrm{L}, \mathrm{pH} \mathrm{5.0}) \mathrm{so}$ as to obtain a 0.2 absorbance unit increase in $10 \mathrm{~min}$ when mixed with an equal volume of NP-G, $2 \mathrm{mmol} / \mathrm{L}$, in the same acetate buffer.

Prepare five tubes, each containing four volumes of acetate buffer (1 mol/L, pH 5.0) and NP-G concentrations of 6.0, $1.5,0.85,0.60$, and $0.45 \mathrm{mmol} / \mathrm{L}$, respectively. Add to each tube one volume of distilled water and one volume of diluted BG, to obtain final NP-G concentrations of 4.00, 1.00, 0.57, 0.40 , and $0.30 \mathrm{mmol} / \mathrm{L}$, respectively. Measure the absorbance increase per minute at $401 \mathrm{~nm}$ during the first 10 min.

Plot the results according to the Michaelis-Menten equation and calculate $K_{\mathrm{m}}$ values for each enzyme. 


\section{$K_{1}$ Determination for $G L$ When the Substrate Is NP-G}

Prepare five tubes, each containing four volumes of acetate buffer (1 mmol/L, pH 5.0) and respective NP-G concentrations of $6.0,1.5,0.85,0.60$, and $0.45 \mathrm{mmol} / \mathrm{L}$. Add to each tube one volume of $1,4-\mathrm{GL}$, obtained by boiling a $100 \mu \mathrm{mol} / \mathrm{L}$ GA solution with one volume of diluted BG. The final NP-G concentrations should be $4.00,1.00,0.57,0.40$, and 0.30 $\mathrm{mmol} / \mathrm{L}$, respectively. Measure the absorbance increase per minute at $401 \mathrm{~nm}$ during the first $10 \mathrm{~min}$. Substitute results in the Michaelis equation modified for competitive inhibition and calculate $K_{\mathbf{i}}$.

Preparation of Reagents for UGA Assay

Prepare sodium acetate buffers $(1 \mathrm{~mol} / \mathrm{L}$ and $2 \mathrm{~mol} / \mathrm{L}, \mathrm{pH}$ 5.0) according to standard procedures.

BG working solution: Dilute BG with acetate buffer (1 $\mathrm{mol} / \mathrm{L}, \mathrm{pH} \mathrm{5.0)}$ to have an absorbance of $0.2 \mathrm{~A}$ in $10 \mathrm{~min}$ when incubated with NP-G ( $1 \mathrm{mmol} / \mathrm{L}$, final concentration).

Substrate (NP-G) working solution (1.72 mmol/L): Prepare substrate freshly each day. Dissolve $16.2 \mathrm{mg}$ of NP-G in $30 \mathrm{~mL}$ of acetate buffer (1 mol/L, $\mathrm{pH} \mathrm{5.0)}$. This quantity suffices for 50 specimens.

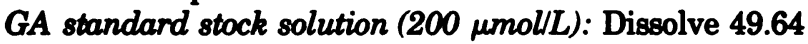
$\mathrm{mg}$ of D-glucaric acid, monopotassium salt, in $1000 \mathrm{~mL}$ of distilled water (stable for one year if stored at $-80^{\circ} \mathrm{C}$ ).

Treatment of Standards and Urine Samples for UGA Determination

Adjust the $\mathrm{pH}$ to between 4.0 and 6.0 by adding glacial acetic acid to those centrifuged urine specimens whose $\mathrm{pH}$ exceeds 6.0. Aliquot $1 \mathrm{~mL}$ of each urine specimen and of standard solution into two sample-tubes, A and B; add to A
$0.2 \mathrm{~mL}$ of $1.5 \mathrm{~mol} / \mathrm{L} \mathrm{HCl}$ and to $\mathrm{B} 0.2 \mathrm{~mL}$ of $1.5 \mathrm{~mol} / \mathrm{L} \mathrm{KOH}$. Boil both aliquots for $45 \mathrm{~min}$ and cool them to room temperature. The resulting $\mathrm{pH}(32)$ will always be $<2.0$ for sample A and $>8.0$ for sample B. After boiling, the samples are stable for $4-5 \mathrm{~h}$. Add $1 \mathrm{~mL}$ of acetate buffer $(2 \mathrm{~mol} / \mathrm{L}, \mathrm{pH}$ 5.0 ), to both $A$ and $B$, then add $0.2 \mathrm{~mL}$ of $1.5 \mathrm{~mol} / \mathrm{L} \mathrm{KOH}$ to $A$ and $0.2 \mathrm{~mL}$ of $1.5 \mathrm{~mol} / \mathrm{L} \mathrm{HCl}$ to $B$. The resulting $\mathrm{pH}$ of the samples will be $5.0 \pm 0.1$.

\section{Assay of UGA}

Program the Cobas Bio or Fara at $37^{\circ} \mathrm{C}$ : (a) to transfer 50 $\mu \mathrm{L}$ of each aliquot and $200 \mu \mathrm{L}$ of NP-G substrate working solution in the reaction cell and to mix them for $5 \mathrm{~min}$; $(b)$ to add, as a starter reagent, $50 \mu \mathrm{L}$ of BG working solution; and (c) to monitor the reaction at $401 \mathrm{~nm}$ for $10 \mathrm{~min}$.

Programming for the Cobas Bio and Fara is shown in Table 2.

\section{Assay of Creatinine (CRE)}

CRE was determined with the "Creatinine Merckotest $A$ " (see Reagents). Specimens from children younger than $6 \mathrm{y}$ were first boiled for $4 \mathrm{~h}$ at $\mathrm{pH} 2.0$, in capped tubes, to convert creatine to creatinine. The initial volume was restored by adding distilled water.

\section{Calculation to Obtain the Concentration of UGA}

For each standard and urine specimen compute $y=\left(1 / A_{A}\right.$ - $1 / A_{B}$ ), where $A_{A}$ and $A_{B}$ are respectively the absorbance after $10 \mathrm{~min}$ minus the absorbance after $30 \mathrm{~s}$ of reaction for the acid-treated (A) and the alkaline-treated (B) aliquot. Compute the regression curve and the coefficient of correlation, $r$, between concentration and $(y)$ the values for the

Table 2. Programs Used in the Cobas Blo and Cobas Fara Centrifugal Analyzers for Urinary D-Glucaric Acid Determination

\begin{tabular}{lc}
\multicolumn{2}{c}{ Cobas Blo } \\
\hline 1. Units & $A$ \\
2. Calculation factor & 1.000 \\
3. Standard 1 concn. & 0 \\
4. Standard 2 concn. & 0 \\
5. Standard 3 concn. & 0 \\
6. Umit & 0 \\
7. Temperature, ${ }^{\circ} \mathrm{C}$ & 37.0 \\
8. Type of analysis & 7 \\
9. Wavelength, $\mathrm{nm}$ & 401 \\
10. Sample vol., $\mu \mathrm{L}$ & 50 \\
11. Diluent vol., $\mu \mathrm{L}$ & 45 \\
12. Reagent vol., $\mu \mathrm{L}$ & 200 \\
13. Incubation time, 8 & 300 \\
14. Start reagent ${ }^{b} \mathrm{vol} ., \mu \mathrm{L}$ & 50 \\
15. Time of first reading, $\mathrm{s}$ & 30.0 \\
16. Time interval, $\mathrm{s}$ & 200 \\
17. No. readings & 04 \\
18. Blanking mode & 1 \\
19. Printout mode & 3
\end{tabular}

\begin{tabular}{|c|c|}
\hline \multicolumn{2}{|c|}{ Cobas Fara } \\
\hline 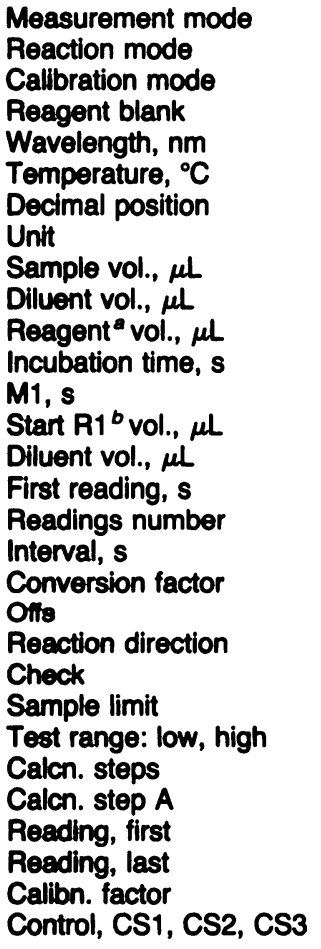 & $\begin{array}{c}\text { Absorb } \\
\text { P-I1-SR1-AO } \\
\text { Factor } \\
\text { No blank } \\
401 \\
37.0 \\
4 \\
\Delta A \\
50 \\
40 \\
200 \\
300 \\
300 \\
50 \\
25 \\
30.0 \\
4 \\
200 \\
1.00000 \\
0.00000 \\
\text { Increase } \\
\text { On } \\
\text { No } \\
\text { No } \\
1 \\
\text { Endpoint } \\
1 \\
4 \\
1.00000\end{array}$ \\
\hline
\end{tabular}


standards. Calibrations are to be rejected as faulty if $r$ is $<0.998$. Divide the uGA concentration by CRE concentration and express results as micromoles of uGA per gram of CRE.

\section{Evaluation of the Method}

Within-day precision: Three specimens (whose average uGA concentrations were measured to be $31.55,69.56$, $121.31 \mu \mathrm{mol} / \mathrm{L}$ ) were analyzed 20 times in the same day.

Between-day precision: Three pools with measured uGA concentrations of $26.09,76.57,124.10 \mu \mathrm{mol} / \mathrm{L}$, respectively, were prepared from urine samples from 200 randomly selected people (including both healthy and sick subjects), aliquoted, and stored at $-15^{\circ} \mathrm{C}$. Aliquots were analyzed (in triplicate) on each of $\mathbf{2 0}$ days.

Detection limit: The detection limit of the method was calculated as $2.6 \times$ the SD of 20 blank determinations, because the true blank is set to zero in each analytical batch.

Analytical recovery: Known amounts of GA (50 or 98 $\mu \mathrm{mol} / \mathrm{L}$ final increase in concentration) were added to 20 different urine specimens and to a pool of 200 urine samples, which were then assayed.

Interference: An aliquot of the interferent substance to be tested was added (1/10 by vol) to a urine pool to obtain the following final concentrations: hemoglobin $5 \mathrm{~g} / \mathrm{L}$, bilirubin $80 \mathrm{mg} / \mathrm{L}$, porphyrins $2 \mathrm{mg} / \mathrm{L}$, ascorbic acid $2 \mathrm{~g} / \mathrm{L}$, glucose 100 $\mathrm{g} / \mathrm{L}$, and albumin up to $18 \mathrm{~g} / \mathrm{L}$. Each of these samples and a control aliquot, to which distilled water (1/10 by vol) was added, were assayed in triplicate.

Method comparison: uGA concentration was measured by both the present method and that of Simmons et al. (26) in urine samples from 152 people (including 21 apparently healthy people, 27 pregnant women, six drug addicts, 27 patients who were undergoing benzodiazepine treatment, and 71 patients on anti-epileptic medication). All samples were assayed in duplicate by each method, and data were subjected to regression analysis.

\section{Reference Interval}

We selected 183 males and 186 females (one to $65 \mathrm{y}$ old) and categorized them by age, according to IFCC recommendations (33). All were apparently healthy people who were undergoing routine analyses at the Hospital of Desio, Milano, Italy. They had no smoking and (or) alcohol abuse habits and did not present any history of medication or drug consumption in the 30 days before specimen collection. The results of their uGA assay were evaluated according to IFCC recommendations (34).

\section{Results}

\section{Choice of the Source of BG}

As a first step to achieve good quality, we studied the $K_{\mathrm{m}}$ for NP-G and the $K_{\mathrm{i}}$ for GL of commercially available BGs (Table 3). BG from Helix pomatia (Boehringer) was used both as supplied and after our purification through affinity chromatography. The enzyme preparation obtained by affinity chromatography performed as well as the preparations (from the same source) that we purified by sequential purification through gel permeation chromatography, ionexchange chromatography, and affinity chromatography on Con-A.

For good sensitivity to GL inhibitor, the $K_{\mathrm{i}}$ for 1,4-GL obtained by boiling GA solutions at $\mathrm{pH} 2.0$, as well as the $K_{\mathrm{m}}$ for NP-G for a high catalytic velocity, should be as low as possible.
Table 3. Kinetic Characteristics of Tested $\boldsymbol{\beta}$ Glucuronidases"

\begin{tabular}{|c|c|c|c|}
\hline \multirow[b]{2}{*}{ Source of enzyme } & $\boldsymbol{K}_{\mathrm{m}}$ & $K_{4}$ & \multirow{2}{*}{$\begin{array}{l}\text { Spectific activity, } \\
\text { A } \times \mathrm{mln}^{-1} \times \\
\mathrm{mg}^{-1}\end{array}$} \\
\hline & \multicolumn{2}{|c|}{ rmoll } & \\
\hline $\begin{array}{l}\text { Helix pomatia (Boehringer) } \\
\text { Helix pomatia (Boehringer) after } \\
\text { affinity chromatography }\end{array}$ & $\begin{array}{l}645 \\
712\end{array}$ & $\begin{array}{r}144 \\
69\end{array}$ & $\begin{array}{l}0.1998 \\
0.3846\end{array}$ \\
\hline $\begin{array}{l}\text { Bovine liver (Sigma) } \\
\text { Helix pomatia (Sigma) after } \\
\text { exclusion chromatography }\end{array}$ & $\begin{array}{r}3108 \\
449\end{array}$ & $\begin{array}{r}734 \\
53\end{array}$ & $\begin{array}{l}0.3978 \\
0.0133\end{array}$ \\
\hline $\begin{array}{l}\text { Patella vulgata (Sigma) } \\
\text { Haliotis midae (Miles) }\end{array}$ & $\begin{array}{l}407 \\
525\end{array}$ & $\begin{array}{r}92 \\
332\end{array}$ & $\begin{array}{l}0.0466 \\
0.0510\end{array}$ \\
\hline \multicolumn{4}{|c|}{ - See text for explanation. 'Performed at the laboratory of Desio Hospital } \\
\hline
\end{tabular}

The $K_{\mathrm{m}}$ and $K_{\mathrm{i}}$ reported in Table 3 show that the best results are to be expected with $\mathrm{BG}$ from Helix pomatia, purified either by affinity chromatography in our laboratory or by gel permeation chromatography as is done by Sigma.

Use of Boehringer's BG purified by affinity chromatography offers advantages, both in terms of much higher specific activity and lower cost.

Bovine-liver BG performs much less satisfactorily with NP-G than with phenolphthalein- $\beta$-glucuronide as substrate.

\section{Sample Preparation}

Transformation of uGA into 1,4-GL is maximal when urine is boiled at a $\mathrm{pH}<2.5$ (data not shown). The specimens must be diluted by $1.5 \mathrm{~mol} / \mathrm{L} \mathrm{HCl}$ or $1.5 \mathrm{~mol} / \mathrm{L} \mathrm{KOH}$ as little as possible, if one is to obtain good precision at the upper limit of the reference interval.

\section{Reaction Conditions}

It is important that the reaction conditions for uGA determination are set to have the greatest difference between the reaction rates of BG in acid-boiled or alkalineboiled urines. This was the case under the following reaction conditions (data not shown): NP-G $1 \mathrm{mmol} / \mathrm{L}$, acetate buffer $0.8 \mathrm{~mol} / \mathrm{L}$, pH 5.0 - the same conditions used by Jung et al. (27).

\section{Validation of the Method}

Calibration curve: Plotting inhibition results according to Dixon (35) gives a linear calibration curve. Linear regression analysis of data from 30 sets of standards under different concentrations (Figure 1) confirms the linearity for uGA concentrations from 10 to $200 \mu \mathrm{mol} / \mathrm{L}$. This is equivalent to the range obtained by the method of Jung et al. (27) and slightly lower than that of the enzymatic method of Marsh (31).

Detection limit: The detection limit for the method is 6.0 $\mu \mathrm{mol} / \mathrm{L}$, which is in agreement with that for most other methods (26-28, 31).

Within-day precision: Data from 20 replicates of uGA determinations at three different concentrations are reported in Table 4. The CV ranges from $4.6 \%$ to $7.9 \%$ at 121.31 and $31.55 \mu \mathrm{mol} / \mathrm{L}$, respectively.

Between-day precision: Between-day precision at three different uGA concentrations was evaluated in triplicate. The data reported in Table 4 demonstrate that precision increases with increasing uGA concentrations.

Our CVs are higher than CVs reported by Jung et al. (27) but are similar to what was reported by Marsh (31), who 


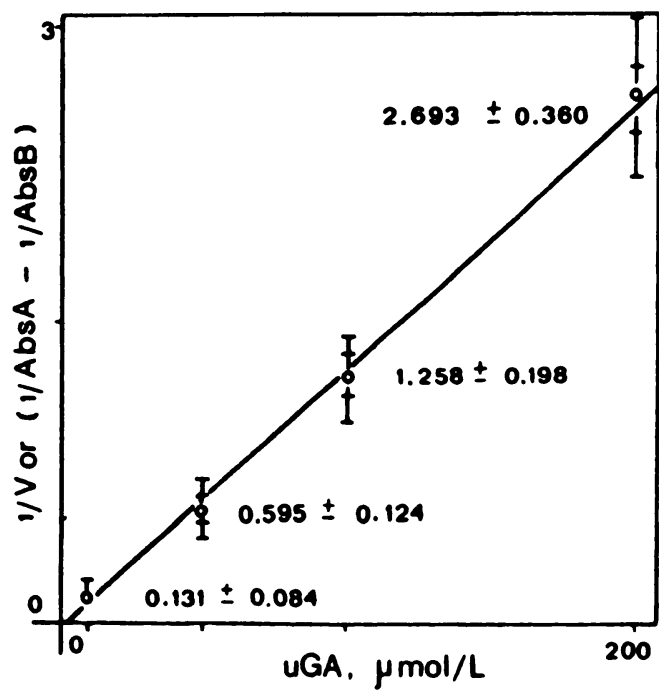

Fig. 1. Calibration curve for urinary D-glucaric acid (UGA) assay by the proposed method

Values determined during 30 days. Points (and bars) represent means (1/A " $\left.1 / A_{B}\right) \pm S D$ (both 1 and 2). Slope $=0.0134(S D=0.00013)$. Intercept $=$ $-0.0268(S D=0.0131)$. Standard error of estimato $=0.0570$. $A$, urine aliquot bolled at pH <2.0. " $\mathrm{B}$, urine aliquot bolled at $\mathrm{pH}>8.0$

analyzed quite a few replicates, and similar to the CVs reported by Colombi et al. (28) and by Sandle and Braganza (36), who used a low-pH enzymatic assay. Simmons et al. (26) do not report precision data for their method, although in our experience its precision is similar to that for the present method.

Analytical recovery: Fifty and $98 \mu \mathrm{mol}$ of GA per liter was added to two sets of 20 different urine samples or to the same pool of 200 urines. uGA was determined in triplicate, and analytical recovery was $\sim 100 \%$ (Table 5).

Interference: No interference was observed by added bilirubin up to $80 \mathrm{mg} / \mathrm{L}$, porphyrins up to $2 \mathrm{mg} / \mathrm{L}$, ascorbic acid up to $2 \mathrm{~g} / \mathrm{L}$, or glucose up to $100 \mathrm{~g} / \mathrm{L}$. Hemoglobin below $5 \mathrm{~g} / \mathrm{L}$ and albumin below $15 \mathrm{~g} / \mathrm{L}$ do not interfere if the specimens are centrifuged at $1000 \times g$ for 5 min after acid-boiling to remove turbidity.

Comparison of methods: The overall correlation of results for 152 different samples between our method and that of Simmons et al. (26) is good $(r=0.978)$. As reported in Figure 2 , the proposed method $(y)$ shows concentrations higher than those obtained by Simmons et al. $(x)$, the equation for the line being $y=1.40 x-2.81\left(S_{y} \cdot x=42.83, \mathrm{SD}\right.$ of slope $=0.02$, and SD of intercept $=4.16$ ).

\section{Reference Interval}

Results of uGA determinations on subjects of the population described above, submitted to the Kolmogorov-Smirnov test (34) for normality of the frequency distribution, did not show any deviation from normality for either sex. Data referring to age groups of apparently healthy people, categorized by sex, are reported in Figure 3.

In children younger than $14 \mathrm{y}$, uGA excretion (expressed in $\mu \mathrm{mol}$ per gram of CRE) does not differ in males (81 subjects, mean value 13.77) and females (84 subjects, mean value 14.59). Values for uGA excretion did not change (Table 6) in the group of 102 men older than $14 \mathrm{y}$ (14.39), whereas higher $(P<0.001)$ values were observed for women older than 14 y (102 subjects, mean value 18.70). The latter also have higher interindividual variability than men, as also reported by March et al. (37).
The reference intervals, 2.5 and 97.5 fractiles, were calculated by parametric methodology (34) for females older than $14 \mathrm{y}$, females younger than $14 \mathrm{y}$, and for males. The fractiles and their $90 \%$ confidence intervals are reported in Table 6.

\section{Discussion}

This method for measurement of uGA excretion is quicker and much simpler than the procedures for uGA determination proposed so far $(22-28,31)$, while providing similar linearity, precision, accuracy, and analytical sensitivity (25-31). Our method allows many tests (80-100/day) to be performed routinely; hitherto, the maximum rate was 40 60 determinations per day (26-27).

To achieve these features we perform the enzymatic determination of uGA with use of a purified BG, whose reaction on the substrate NP-G can be easily monitored at pH 5.0 (the pH of the reaction solution), especially in a centrifugal analyzer.

This fact makes unnecessary the usual stopping of the NP-G enzymatic hydrolysis by adding $\mathrm{NaOH}(26,27)$ to the reaction solution to increase its $\mathrm{pH}$ to alkaline values before reading. In fact, at pH 5.0 the NP-G hydrolysis by BG produces an absorbance increase linearly related to the concentration of the 4-nitrophenol released and measurable between 400 and $405 \mathrm{~nm}$ (the nonspecific absorbance of urine is too high below $400 \mathrm{~nm}$ ). Under these conditions and in the absence of inhibitors, NP-G enzymatic hydrolysis produces a typical absorbance increase of $\sim 0.20 \mathrm{~A}$ at 401 nm.

BGs from bovine liver and from Helix pomatia as crude extracts need to be purified, because they are not suitable to measure uGA under the conditions described. Purification of BG from Helix pomatia (Boehringer) is very simple in comparison with the purification specified in some methods,

\begin{tabular}{|c|c|c|c|}
\hline \multirow[b]{2}{*}{$n$} & \multicolumn{2}{|c|}{ UGA concentration, $\mu \mathrm{mol} / \mathrm{L}$} & \multirow[b]{2}{*}{ CV, $\%$} \\
\hline & Maan & SD & \\
\hline \multicolumn{4}{|l|}{ Within-day } \\
\hline $\begin{array}{l}20 \\
20 \\
20 \\
\text { Between-day }\end{array}$ & $\begin{array}{r}31.55 \\
69.56 \\
121.31\end{array}$ & $\begin{array}{l}2.50 \\
4.70 \\
5.58\end{array}$ & $\begin{array}{l}7.9 \\
6.8 \\
4.6\end{array}$ \\
\hline $\begin{array}{l}20(3) \\
20(3) \\
20(3)\end{array}$ & $\begin{array}{r}26.09 \\
76.57 \\
124.10\end{array}$ & $\begin{array}{l}3.01 \\
6.72 \\
6.20\end{array}$ & $\begin{array}{r}11.5 \\
8.8 \\
5.0\end{array}$ \\
\hline
\end{tabular}

In parentheses: number of replicates for each of $n$ determination.

Table 5. Analytical Recovery of Urinary D-Glucaric Acid (UGA)

\begin{tabular}{|c|c|c|c|}
\hline \multicolumn{3}{|c|}{ UGA conen, $\mu \mathrm{mol} / \mathrm{L}$} & \multirow{2}{*}{$\begin{array}{l}\text { Mean uGA } \\
\text { recovered, } \mu \mathrm{mol} / \mathrm{L} \\
\text { (and SE, SD) }\end{array}$} \\
\hline & Added & $\begin{array}{l}\text { Moan recovered } \\
\text { (and SE, SD) }\end{array}$ & \\
\hline
\end{tabular}

Recovery for different urine samples

$20 \quad 50 \quad 49.81(3.13,5.42) \quad 99.6(6.27,10.86)$

$20 \quad 98 \quad 102.19(6.66,11.53) \quad 104.3(6.80,11.78)$

Recovery for a pool of unine samples ${ }^{b}$

$20 \quad 50 \quad 50.48(3.36,5.82) \quad 100.9(6.72,5.94)$

$20 \quad 98 \quad 98.01(3.39,5.88) \quad 100.0(6.78,6.00)$

-Each of the 20 urine samples was divided into three aliquots and assayed in triplicate.

- A pool of 200 urine samples was divided into three aliquots. Each aliquot was tested in triplicate for 20 days. 

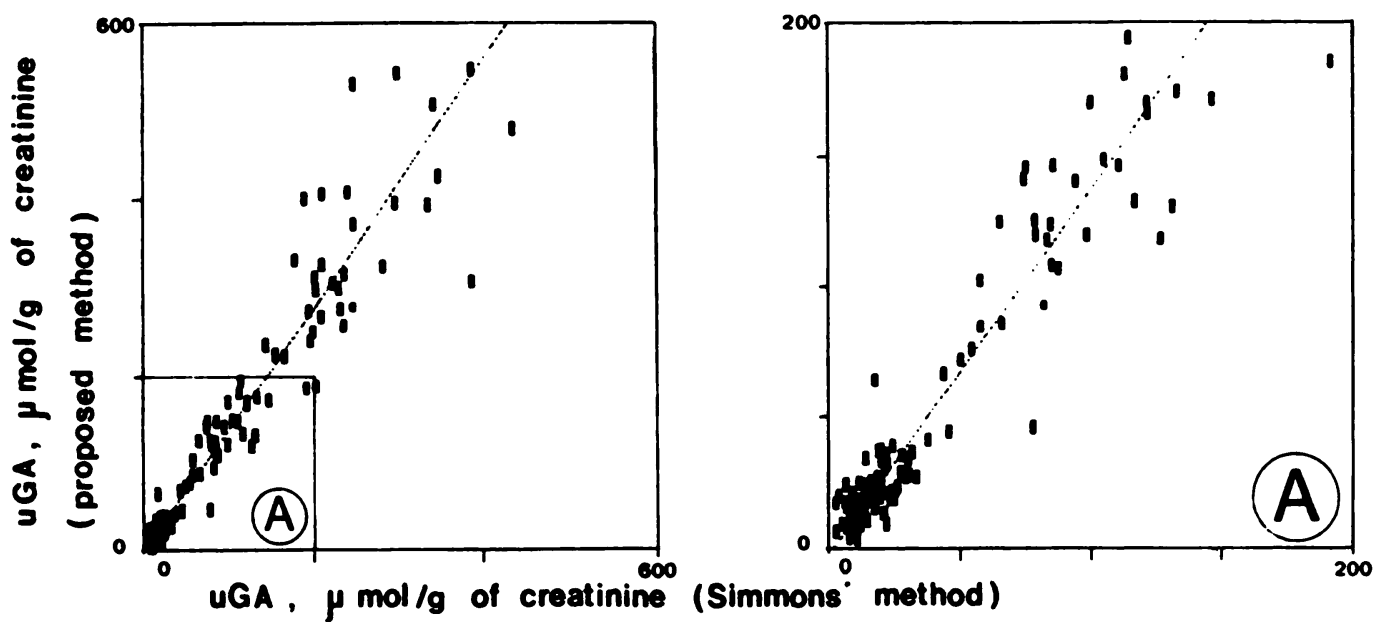

Fig. 2. Comparison of urinary D-glucaric acid (UGA) determination between the proposed method (b) and another (26) method ( $x$ ) meet $A$ shows the linear range of the proposed method. Slope $=1.40(S D=0.02)$; intercept $=-2.81(S D=4.16) ; S_{r x}=42.83 ; n=152 ; r=0.978$

namely those for BG from rat liver $(25,27)$ and mouse kidney (38). In fact, it can be easily performed in any clinical chemistry laboratory with a single chromatographic step, passing BG through Con-A Sepharose (see Methods); alternatively, commercially available BG purified by gel permeation chromatography (Sigma) can be used.

With our method we have obtained uGA values $\sim 40 \%$ higher than those obtained by the method of Simmons et al. (26) (see Figure 2). One reason could be that their method, like other methods based on BG inhibition, may be inaccurate because of the underestimate produced by nonspecific BG inhibition, as stated by Fiedler et al. (39). In fact, at the

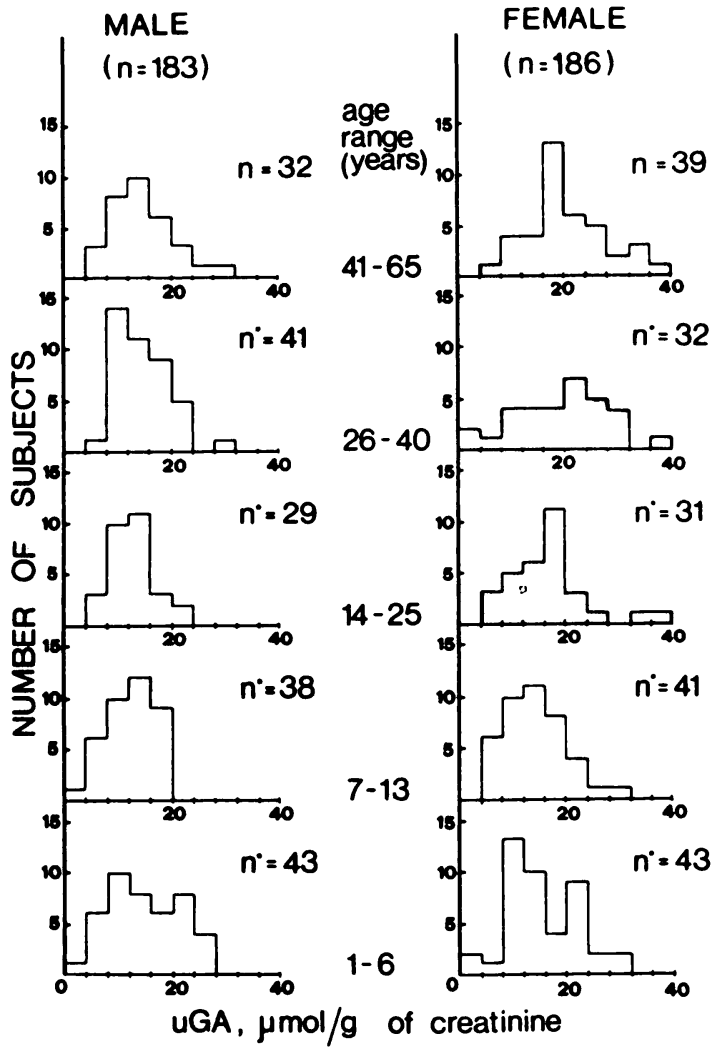

Fig. 3. Urinary D-glucaric acid (UGA) excretion by apparently healthy males and females according to age groups

$x=$ LQA, $\mu \mathrm{moV} g$ of creetinine. $y=$ number of subjects. Data are for males, and for fomales $<14 \mathrm{y}$, except in the three graphs top right, which are for females older than $14 \mathrm{y}$ usual pH (5.0) of a BG assay, uGA (non-inhibitory) in the alkaline-treated aliquot is partly converted to GL (inhibitory) during the incubation and reaction intervals, which usually total $30-60 \mathrm{~min}(31,39)$. Our method avoids such a nonspecific inhibition because the aliquots remain only briefly at $\mathrm{pH} 5.0$ before reaction (about $15 \mathrm{~min}$ total for transfer operations and incubation) and because the use of an automated analyzer allows the reaction time to be shortened to $10 \mathrm{~min}$. Up to a GA concentration of $200 \mu \mathrm{mol}$ $L, G L$ production in the $B$ aliquots is negligible, as proved by lack of BG activity inhibition in alkali-treated GA standards.

Moreover, Marsh (31) has reported that uGA conversion to pyruvate and subsequent enzymatic determination by means of lactate dehydrogenase gives higher values than those obtained by a modified method of Simmons et al. (26). Marsh (31) considered the former to be more reliable. These data support our results.

Reported normal reference values for uGA excretion differ greatly $(37,39-41)$, probably owing to the different methods used, to differences arising from standardization with GA or 1,4-GL, and to the small reference groups studied.

Because of its inherent specificity, the gas-liquid chromatographic method developed by Gangolli et al. (23) seems to provide the most reliable results for a comparison, even though they studied only six subjects. These authors reported a mean uGA excretion of $28.3 \mu \mathrm{mol} / 24 \mathrm{~h}(7.02 \mathrm{mg} / 24 \mathrm{~h})$, equivalent to 18.9-21.8 $\mu \mathrm{mol}$ per gram of CRE (assuming the mean daily excretion of creatinine to be $1.5 \mathrm{~g}$ in the male and $1.3 \mathrm{~g}$ in the female). The mean uGA values obtained for a large sample population by our method (14.07 $\mu \mathrm{mol} / \mathrm{g} \mathrm{CRE}$

Table 6. Reference Values for Urinary D-Glucaric Acid (UGA) Excretion In Morning Urines from Apparently Healthy People

\begin{tabular}{|c|c|c|c|c|}
\hline \multirow[b]{2}{*}{$\begin{array}{c}\text { Croup } \\
\text { (and age range, } y \text { ) }\end{array}$} & \multirow[b]{2}{*}{$\begin{array}{l}\text { No. of } \\
\text { subjects }\end{array}$} & \multicolumn{3}{|c|}{$\begin{array}{l}\text { uGA concentration, } \\
\mu \mathrm{mov} / \mathrm{g} \text { of creatinine }\end{array}$} \\
\hline & & Mean & SD & $\begin{array}{l}0.95 \text { reterence limits } \\
\text { (0.90 confidence } \\
\text { Interval for each IImit) }\end{array}$ \\
\hline $\begin{array}{l}\text { Males } \\
(1-65)\end{array}$ & 183 & 14.07 & 5.34 & $\begin{array}{c}3.6 \text { to } 24.5 \\
(2.5-4.7)(23.4-25.6)\end{array}$ \\
\hline $\begin{array}{c}\text { Females } \\
(1-13)\end{array}$ & 84 & 14.59 & 6.26 & $\begin{array}{c}2.3 \text { to } 26.9 \\
(0.4-4.2)(25.0-28.8)\end{array}$ \\
\hline $\begin{array}{l}\text { Females } \\
(14-65)\end{array}$ & 102 & 18.70 & 7.91 & $\begin{array}{c}3.2 \text { to } 34.2 \\
(0.9-5.5)(31.9-36.5)\end{array}$ \\
\hline
\end{tabular}


in 183 males and $18.70 \mu \mathrm{mol} / \mathrm{g}$ CRE in 102 females older than 14 y) agree reasonably well with their results.

Only Colombi et al. (40) report reference values derived from a large population of adults. They found a mean uGA excretion of $26.94 \mu \mathrm{mol}$ per gram of CRE for $402 \mathrm{men}, 29.67$ $\mu \mathrm{mol} / \mathrm{g}$ for 171 women. The higher values they obtained in comparison with our results can be expected, because their method (28) cannot measure the effects of nonspecific BG inhibitors in the matrix $(25,31)$.

Fiedler et al. (39) and Colombi et al. (40) also published values for UGA excretion per gram of CRE that were higher for women than for men, but no data from children were reported.

Steinberg et al. (29), who reported uGA excretion in mmol per mole of CRE, found a wider reference interval for children younger than $15 \mathrm{y}$ than for adults. We did not find such a difference when we treated the children's urine samples to transform the excreted creatine into creatinine (see Methods); in fact, low values for creatinine in urine from children younger than $6 \mathrm{y}$, because of incomplete transformation of creatine to creatinine, give rise, by calculation, to apparently high results for uGA excretion.

In conclusion, the procedure described here for enzymatic measurement of uGA excretion is characterized by good sensitivity, precision comparable with that reported for other methods $(28,31)$, good specificity, accuracy excelling that for existing methods $(26,28)$, and faster analysis.

Finally we would like to remember that it is still an open question as to what is the best indicator of hepatic microsomal enzyme induction. Price et al. (21) support the view that, for low doses of phenobarbital, antipyrine clearance is more sensitive than $6 \beta$-hydroxycortisol or uGA. According to Sandle and Braganza (36), uGA would be a poor indicator of pancreatic monooxygenase induction. Recent reports $(8$, 17,18 ) underline the usefulness of uGA determination as a marker of enzyme induction after administration of anticonvulsant drugs (17) and (or) any of a long list of other drugs (18). The correlation of $u G A$ with $6 \beta$-hydroxycortisol varies in different reports, depending on the administered drugs $(13,17,18)$. These differences can probably be explained with the hypothesis that "these tests probably reflect the activity of different but overlapping parts of the microsomal enzyme system" (8). This same author (8) stresses the potentially useful application of uGA determination for studies of microsomal enzyme function in occupational medicine. A more substantiated decision on the use of these tests can be made when a much larger number of people is studied as compared with the small groups investigated hitherto. Considering this important goal, the usefulness of our method is confirmed by the ease with which it permits, for health control or epidemiological studies, the follow-up of large populations of special subjects such as pregnant women, drug addicts, and people exposed to environmental toxic substances.

\section{References}

1. Nebert DW, Gonzalez FJ. P450 genes: structure, evolution, and regulation [Review]. Annu Rev Biochem 1987;56:945-93.

2. Goldberg DM. The expanding role of microsomal enzyme induction, and its implications for clinical chemistry [Review]. Clin Chem 1980;26:691-9.

3. Park BK, Breckenridge AM. Clinical implications of enzyme induction and enzyme inhibition [Review]. Clin Pharmacokinet 1981;6:1-24.
4. Bolt HM, Kappus H, Bolt M. Effect of rifampicin treatment on the metabolism of oestradiol and $17 \alpha$-ethinyloestradiol by human liver microsomes. Eur J Clin Pharmacol 1975;8:301-7.

5. Ratanasavanh D, Tazi A, Galteau MM, Siest G. Localization of gamma-glutamyltransferase in subcellular fractions of rat and rabbit liver: effect of phenobarbital. Biochem Pharmacol $1979 ; 28: 1263-5$.

6. Sotaniemi EA, Pelkonen RO, Puukka M. Measurement of hepatic drug-metabolizing enzyme activity in man. Comparison of three different assays. Eur J Clin Pharmacol 1980;17:267-74.

7. Kappas A, Alvares AP, Anderson KE, et al. Effect of charcoalbroiled beef on antipyrine and theophylline metabolism. Clin Pharmacol Ther 1978;23:445-50.

8. Dossing M. Noninvasive assessment of microsomal enzyme activity in occupational medicine: present state of knowledge and future perspectives. Int Arch Occup Environ Health 1984;53:20518.

9. Rosalki SB, Tarlow D, Rau D. Plasma gamma glutamyltranspeptidase elevation in patients receiving enzyme inducing drugs. Lancet 1971;ii:376-7.

10. Whitfield JB, Moss DW, Neale G, Orme M, Breckenridge A. Changes in plasma $r$ glutamyl transpeptidase activity associated with alterations in drug metabolism in man. $\mathrm{Br}$ Med $\mathrm{J}$ 1973;1:3168.

11. Martin PJ, Martin JV, Goldberg DM. $\gamma$-Glutamyl transpeptidase, triglycerides, and enzyme induction. Br Med J 1975;i:17-8.

12. Hildebrandt AG, Roots I, Speck M, Saalfrank K, Kewitz H. Evaluation of in vivo parameters of drug metabolizing enzyme activity in man after administration of clemastine, phenobarbital or placebo. Eur J Clin Pharmacol 1975;8:327-36.

13. Ohnhaus EE, Park BK. Measurement of urinary 6- $\beta$-hydroxycortisol excretion as an in vivo parameter in the clinical assessment of the microsomal enzyme-inducing capacity of antipyrine, phenobarbitone and rifampicin. Eur J Clin Pharmacol 1979;15:139-45.

14. Aarts EM. Evidence for the function of D-glucaric acid as an indicator for drug induced enhanced metabolism through the glucuronic acid pathway in man. Biochem Pharmacol 1965;14:359-63.

15. Hunter J, Maxwell JD, Carrella M, Stewart JD, Williams R. Urinary D-glucaric acid excretion as a test for hepatic enzyme induction in man. Lancet 1971;i:572-5.

16. Latham AN. D-Glucaric acid as an index of hepatic enryme induction by anticonvulsant drugs in man. J Pharm Pharmacol 1974;26:284-6.

17. Perucca E, Hedges A, Makki KA, Ruprah M, Wilson JF, Richens A. A comparative study of the relative enzyme inducing properties of anticonvulsant drugs in epileptic patients. Br J Clin Pharmacol 1984;18:401-10.

18. Heinemeyer G, Roots I, Lestau P, Klaiber HR, Dennhardt R. DGlucaric acid excretion in critical care patients-comparison with $6 \beta$-hydroxycortisol excretion and serum $\gamma$-glutamyltranspeptidase activity and relation to multiple drug therapy. $\mathrm{Br} \mathrm{J}$ Clin Pharmacol 1986;21:9-18.

19. Ideo G, Bellati G, Bellobuono A, Mocarelli P, Marocchi A, Brambilla P. Increased urinary D-glucaric acid excretion by children living in an area polluted with tetrachlorodibenzoparadioxin (TCDD). Clin Chim Acta 1982;120:273-83.

20. May G. Tetrachlorodibenzodioxin: a survey of subjects ten years after exposure. $\mathrm{Br} \mathrm{J}$ Ind Med 1982;39:128-35.

21. Price DE, Mehta A, Park BK, Hay A, Feely MP. The effect of low-dose phenobarbitone on three indices of hepatic microsomal enzyme induction. Br J Clin Pharmacol 1986;22:744-7.

22. Ishidate $M$, Matsui $M$, Okada $M$. Biochemical studies on glucuronic acid and glucaric acid. 1. Quantitative chemical determination of D-glucaric acid in urine. Anal Biochem 1965;11:176-89.

23. Gangolli SD, Longland RC, Shilling WH. A gas-liquid chromatographic method for the determination of D-glucaric acid in urine. Clin Chim Acta 1974;50:237-43.

24. Laasko EI, Tokola RA, Hirvisalo RL. Determination of Dglucaric acid by high-performance liquid chromatography. J Chromatogr 1983;278:406-11.

25. Marsh CA. Metabolism of D-glucuronolactone in mammalian 
8ystems. Identification of D-glucaric acid as a normal constituent of urine. Biochem J 1963;86:77-86.

26. Simmons CJ, Davis M, Dordoni B, Williams R. Urinary Dglucaric acid assay by an improved enzymatic procedure. Clin Chim Acta 1974;51:47-51.

27. Jung $K$, Scholn D, Schreiber G. Improved determination of Dglucaric acid in urine. Clin Chem 1981;27:422-6.

28. Colombi A, Maroni M, Antonini C, Cassina T, Gambini A, Fod V. Low-pH method for the enzymatic assay of D-glucaric acid in urine. Clin Chim Acta 1983;128:337-47.

29. Steinberg KK, MacNeil ML, Karon JM, et al. Assessment of 2,3,7,8-tetrachlorodibenzo-p-dioxin exposure using a modified Dglucaric acid assay [Abstract]. J Toxicol Environ Health 1985;16:743-52.

80. MacNeil ML, Steinberg KK, Yeager PR, Smith SJ. A semiautomated procedure for urinary D-glucaric acid using a centrifugal analyzer [Abstract]. J Anal Toxicol 1986;10:15-7.

31. Marah CA. An enzymatic determination of D-glucaric acid by conversion to pyruvate. Anal Biochem 1985;145:266-72.

32. Latham AN. Effect of in vitro changes in urinary $\mathrm{pH}$ on the enrymatic measurement and daily variation in excretion of Dglucaric acid. J Pharm Pharmacol 1975;27:612-5.

33. International Federation of Clinical Chemistry (IFCC) Scientific Committee, Clinical Section, Expert panel on theory of reference values. The theory of reference values. Part 2. Selection of individuals for the production of reference values. $\mathrm{J}$ Clin Chem Clin Biochem 1984;22:203-8.
34. International Federation of Clinical Chemistry (IFCC) Scientific Committee, Clinical Section, Expert panel on theory of reference values. The theory of reference values. Part 5. Statistical treatment of collected reference values. Determination of reference limits. J Clin Chem Clin Biochem 1983;21:749-60.

35. Dixon $M$. The determination of enzyme inhibitor constants. Biochem J 1953;55:170-1.

36. Sandle LN, Braganza JM. An evaluation of the low-pH enzymatic assay of urinary D-glucaric acid, and its use as a marker of enryme induction in exocrine pancreatic disease. Clin Chim Acta 1987;162:245-56.

37. March J, Turner WJ, Shanley J, Field J. Values for urinary excretion of D-glucaric acid by normal individuals Clin Chem 1974;20:1155-8.

38. Lin WC, Orcutt MI, Fishman WH. Purification and characterization of mouse kidney beta-glucuronidase. J Biol Chem 1975;250:4737-43.

39. Fiedler K, Schröter E, Cramer H. Glucaric acid excretion. Analysis of the enzymatic assay and finding in smokers and nonsmokers. Eur J Clin Pharmacol 1980;18:429-32.

40. Colombi A, Maroni M, Antonini C, Fait A, Zoochetti C, Foà V. Influence of sex, age, and smoking habits on the urinary excretion of D-glucaric acid. Clin Chim Acta 1983;128:349-58.

41. Davidson DC, McIntosh WB, Ford JA. Aseessment of plasms glutamyltranspeptidase activity and urinary D-glucaric acid excretion as indices of enryme induction. Clin Sci Mol Med 1974;47:279 83. 